\title{
Phytochemistry and Quantification of Polyphenols in Extracts of the Asteraceae Weeds From Diamantina, Minas Gerais STATE, BRAZIL ${ }^{1}$
}

\author{
Fitoquímica e Quantificação de Polifenóis em Extratos de Plantas Daninhas Asteraceae de \\ Diamantina, Minas Gerais, Brasil \\ PETACCI, F. ${ }^{2}$, TAVARES, W.S. ${ }^{3}$, FREITAS, S.S. ${ }^{2}$, TELES, A.M. ${ }^{4}$, SERRÃO, J.E..$^{5}$ and \\ ZANUNCIO, J.C. ${ }^{6}$
}

\begin{abstract}
Asteraceae weeds are rich in chemicals that have biological and pharmaceutical activities. The aims of this work were to describe the phytochemistry and quantify the polyphenols in ethanol extracts from leaves of 12 species of Asteraceae weeds collected in Diamantina, Minas Gerais State, Brazil. The screening of Asteraceae extracts revealed the presence of tannins, steroids, triterpenes, anthocyanins, and flavonoids. The total phenolic content was high in extracts of Lychnophora ericoides (147.97 \pm 2.66$)$, Lepidaploa lilacina (141.11 $\pm 1.99)$, and Eremanthus elaeagnus (134.61 \pm 7.81 ) and low in extracts of Lychnophora ramosissima $(32.65 \pm 0.70)$, and Lychnophora sp. (54.03 \pm 0.73$)$. Extracts of Asteraceae weeds from Diamantina could have potential for biological studies that are searching for new pesticides and drugs.
\end{abstract}

Keywords: Asteraceae, Campos rupestres, Diamantina, Pesticides, Phytochemistry, Polyphenols.

\begin{abstract}
RESUMO - Plantas daninhas Asteraceae são ricas em substâncias químicas com atividades biológicas e farmacêuticas. Os objetivos deste trabalho foram descrever a fitoquímica e quantificar os polifenóis em extratos etanólicos de folhas de 12 espécies de plantas daninhas Asteraceae coletadas em Diamantina, Minas Gerais, Brasil. A triagem de extratos de Asteraceae revelou a presença de taninos, esteroides, triterpenos, antocianinas e flavonoides. O conteúdo de fenóis totais foi alto para extratos de Lychnophora ericoides (147,97 $\pm 2,66)$, Lepidaploa lilacina $(141,11 \pm 1,99)$ e Eremanthus elaeagnus $(134,61 \pm 7,81)$ e baixo em extratos de Lychnophora ramosissima $(32,65 \pm 0,70) e$ Lychnophora $s p$. (54,03 $\pm 0,73)$. Extratos de plantas daninhas Asteraceae de Diamantina podem ter potencial em estudos biológicos que estão à procura para pesticidas e drogas.
\end{abstract}

Palavras-chave: Asteraceae, campos rupestres, Diamantina, pesticidas, fitoquímica, polifenóis.

\section{INTRODUCTION}

Asteraceae comprises 8 to $10 \%$ of angiosperm species, with 1,600-1,700 genera around 24,000 species (Funk et al., 2009). Approximately 580 genera and 8,040 species are recorded in Tropical America (Okunade, 2002) and 274 genera and 2,024 species occur in Brazil (Nakajima et al., 2010). Asteraceae species are abundant in arid, semi-arid and high altitudes, such as campos rupestres, but few in tropical forests (Hind, 1993). The chemical-biological potential of the Asteraceae species may be lost by deforestation, and the fact that some of its species are endemic only aggravates the situation (Teles et al., 2009).

\footnotetext{
Recebido para publicação em 26.2.2011 e aprovado em 12.8.2011.

2 Dep. de Química, Universidade Federal de Goiás, 75704-020 Catalão, Goiás, Brasil, <petacci_f@hotmail.com, sil-freitas@hotmail.com>; ${ }^{3}$ Dep. de Fitotecnia, Universidade Federal de Viçosa - DFT/UFV, 36570-000 Viçosa, Minas Gerais, Brasil, <wagner.tavares@ufv.br>; ${ }^{4}$ Dep. de Biologia Geral, Universidade Federal de Goiás, 74001-970 Goiânia, Goiás, Brasil, <teles@icb.ufg.br>; ${ }^{5}$ Dep. de Biologia Geral, DBG/UFV, < jeserrao@ufv.br>; ${ }^{6}$ Dep. de Biologia Animal, DBA/UFV, <zanuncio@ufv.br>.
} 
The potential for generating a pesticide from natural compounds found in plants of this family has been studied since 1940, and thus stimulated the development of pyrethroids from pyrethrins. This advancement was important for the research and development of new compounds utilizing the insecticidal activity of this botany family (Isman, 2006). The mortality of larvae of Aedes fluviatilis (Diptera: Culicidae), vector of malaria, dengue, and yellow fever in Brazil, was high with the use of ethanol extracts of 83 Asteraceae species, especially those of Tagetes minuta, and Eclipta paniculata (Macêdo et al., 1997). Ethanol extracts of Asteraceae had deleterious and deterrent effects on eggs and caterpillars of Spodoptera frugiperda (Lepidoptera: Noctuidae) and selectivity to Trichogramma pretiosum (Hymenoptera: Trichogrammatidae) and Telenomus (Hymenoptera: Scelionidae), but extracts of Lychnophora ericoides, Lychnophora ramosissima, and Echinocoryne holosenicea were considered the most promising for Integrated Pest Management (Tavares et al., 2009).

The finding of new compounds for pest control is important for agriculture in Brazil (Van Loon et al., 2000; Tavares et al., 2010a, b). Secondary metabolites such as the alkaloids nicotine from Nicotiana tabacum (Solanaceae), and piperine from Piper nigrum (Piperaceae); the rotenoid rotenone from Derris spp. (Fabaceae); the limonoid azadirachtin from Azadirachta indica, and roclagamides from Aglaia spp. (Meliaceae) are used for household and agricultural pest control (Isman, 2006; Petacci et al., 2010; Tavares et al., 2011). Phenolic compounds such as flavonoids, tannins, and anthocyanins are widely distributed in plants. They may affect food preference and pre- and post-ingestion of food (Bernays et al., 1989) and reduce damage by herbivores (Mueller-Harvey, 2001; Schofield et al., 2001). In addition, compounds can be selective insecticides to parasitoids and predators (Zanuncio et al., 1998, 2003, 2005; Vianna et al., 2009).

The aims of this study were to evaluate the presence of some classes of secondary metabolites and quantify the total polyphenol contents in ethanol extracts of 12 species of Asteraceae weeds from campos rupestres in Diamantina, Minas Gerais State, Brazil.

\section{MATERIAL AND METHODS}

Leaves of 12 species of Asteraceae weeds (Table 1) were collected from January 2005 to February 2006 in campos rupestres of the "Serra do Espinhaço Meridional" in Diamantina, Minas Gerais State, Brazil. The samples were deposited in the herbarium of the Department of Biological Sciences, Federal University of Jequitinhonha and Mucuri Valleys in Diamantina, Minas Gerais State, Brazil. The altitude of this region is $1,296 \mathrm{~m}$ with annual temperature of $18.1{ }^{\circ} \mathrm{C}$. January is the month that receives the most rain with $307.0 \mathrm{~mm}$, followed by December with 264.3, November with 222.0, and March with $166.9 \mathrm{~mm}$. The driest months are June, July, and August, with $7.7,8.1$, and $16.7 \mathrm{~mm}$ of rainfall, respectively.

Six hundred grams of fresh leaves from each species of Asteraceae were extracted at $25 \pm 2{ }^{\circ} \mathrm{C}$ temperature with ethanol (1.0 liter) for seven days. The extracts were concentrated in a vacuum rotary-evaporator. Yield (\%) was obtained from the mass of the residue in relation to the original vegetal material.

The classes of secondary metabolites and the reagents used in the detection of them were anthocyanins (vanillin $+\mathrm{HCl}$ ), alkaloids (Dragendorff), flavonoids (magnesium metal + HCl), steroids, triterpenes (LiebermanBurchard), and tannins ( $\mathrm{FeCl}_{3}$ solution to $3 \%$ ).

Polyphenols of Asteraceae were quantified according to the Folin-Ciocalteau method. The calibration curve was prepared with gallic acid at concentrations of $0.2,1.0,10.0,20.0,40.0$, and $100.0 \mu \mathrm{g} \mathrm{mL}^{-1}$ and the extracts dissolved in methanol $\left(500.0 \mu \mathrm{g} \mathrm{mL}^{-1}\right)$. One milliliter of each solution was mixed with $5.0 \mathrm{~mL}$ of FolinCiocalteau reagent, stirred and left to stand between five and eight minutes for the analysis of standard curve and samples. Next, $4.0 \mathrm{~mL}$ of a solution of $\mathrm{Na}_{2} \mathrm{CO}_{3}(7.5 \%)$ were added to this solution and the mixture allowed tostand for two hours in the dark. After this period, the reading of the absorbance of this mixture was made with $\lambda=740 \mathrm{~nm}$. The concentration of polyphenols in the extracts was obtained using the calibration curve equation and the results expressed in milliequivalents of gallic acid (mg g-1 of extract mass). The samples were analyzed in triplicate and the results expressed as mean \pm standard deviation. 
Table 1 - Scientific name, yield from ethanol extracts of leaves $\left(\% \mathrm{~m} \mathrm{~m}^{-1}\right)$, and record number of 12 Asteraceae species deposited in the herbarium (DIAM) of the Department of Biological Sciences of the Federal University of Jequitinhonha and Mucuri Valleys in Diamantina, Minas Gerais State, Brazil

\begin{tabular}{|l|c|c|}
\hline \multicolumn{1}{|c|}{ Scientific name } & Yields & Voucher \\
\hline Ageratum fastigiatum (Gardner) R.M. King \& H. Rob. & 4.90 & DIAM 1448 \\
\hline Chromolaena chaseae (B.L. Rob.) R.M. King \& H. Rob. & 3.45 & DIAM 1439 \\
\hline Eremanthus elaeagnus (Mart. ex DC.) Sch.Bip. & 2.74 & DIAM 1485 \\
\hline Lepidaploa lilacina (Mart. ex DC.) H. Rob. & 4.66 & DIAM 1441 \\
\hline Lepidaploa rufogrisea (A.St.-Hil.) H. Rob. & 4.13 & DIAM 1444 \\
\hline Lychnophora sp. & 4.15 & DIAM 1447 \\
\hline Lychnophora ericoides Mart. & 4.50 & DIAM 1440 \\
\hline Lychnophora ramosissima Gardner & 3.88 & DIAM 1449 \\
\hline Mikania nummularia DC. & 2.08 & DIAM 1445 \\
\hline Trichogonia villosa (Spreng). Sch.Bip. ex Baker & 4.87 & DIAM 1443 \\
\hline Trixis glutinosa D. Don. & 5.80 & DIAM 1442 \\
\hline Echinocoryne holosenicea (Mart. ex DC.) H. Rob. & 3.96 & DIAM 1446 \\
\hline
\end{tabular}

\section{RESULTS AND DISCUSSION}

The identification of species, the voucher specimens number, and yields of the extracts $\left(\mathrm{m} \mathrm{m}^{-1}\right)$ that ranged between 2.08 (Mikania nummularia) to $5.80 \%$ (Trixis glutinosa) are shown in Table 1. The extract yield from Asteraceae weeds was similar to the yield of those evaluated for insecticidal activity against $S$. frugiperda and selectivity to natural enemies of this pest (Tavares et al., 2009), confirming the efficacy of the procedure and the extracts' viability for usage on a larger scale.

The phytochemical screening of extracts of Asteraceae weeds revealed the presence of some secondary metabolites. The test for tannins was positive in all samples, even when diluted 10 folds, indicating a high concentration of this class of secondary metabolite, which was quantified. Flavonoids were detected in Trichogonia villosa and T. glutinosa; and anthocyanins in Lychnophora rufogrisea, Lychnophora sp., M. nummularia, and T. glutinosa. Chromolaena chaseae, L. rufogrisea, Lychnophora sp., L. ericoides, L. ramosissima, M. nummularia, T. glutinosa, and $E$. holosenicea had steroids and triterpenes, probably because of phytosteroids such as stigmasterol and sitosterol, widely distributed in plants. Moreover, none of the samples showed alkaloids (Table 2).
The absence of alkaloids in the extracts suggests that Asteraceae may be susceptible to herbivores. This is indicated by the higher preference of $S$. frugiperda and Agrotis ipsilon (Lepidoptera: Noctuidae) for young plants with lower amounts of these compounds (Potter et al., 2008), and the lower survival and development rates of ants among plants rich in the same, thus confirming the fact that basic substances such as alkaloids may affect the digestive tract of insects (López \& Potter, 2000).

Table 2 - Phytochemical screening of ethanolic extracts of leaves of 12 species of Asteraceae (tannin-Ta, alkaloids- Al, flavonoids- Fl, steroids and triterpenes-St/Tr, and anthocyanin-An)

\begin{tabular}{|l|c|c|c|c|c|}
\hline \multicolumn{1}{|c|}{ Species } & $\mathrm{Ta}$ & $\mathrm{Al}$ & $\mathrm{Fl}$ & $\mathrm{St} / \mathrm{Tr}$ & $\mathrm{An}$ \\
\hline Ageratum fastigiatum & ++ & -- & -- & -- & -- \\
\hline Chromolaena chaseae & ++ & -- & -- & + & -- \\
\hline Eremanthus elaeagnus & ++ & -- & -- & -- & -- \\
\hline Lepidaploa lilacina & ++ & -- & -- & -- & -- \\
\hline Lepidaploa rufogrisea & ++ & -- & -- & + & + \\
\hline Lychnophora sp. & ++ & -- & -- & + & + \\
\hline Lychnophora ericoides & ++ & -- & -- & + & -- \\
\hline Lychnophora ramosissima & ++ & -- & -- & + & -- \\
\hline Mikania nummularia & ++ & -- & -- & + & + \\
\hline Trichogonia villosa & ++ & -- & + & -- & -- \\
\hline Trixis glutinosa & ++ & -- & + & + & + \\
\hline Echinocoryne holosenicea & ++ & -- & -- & + & -- \\
\hline
\end{tabular}

$(-)=$ Absence; $(+)=$ Presence; $(++)=$ Majority.

Planta Daninha, Viçosa-MG, v. 30, n. 1, p. 9-15, 2012 
Moreover, Tellervo zoilus (Lepidoptera: Ithomiinae) and Coccinellidae were more resistant and their eggs more vigorous with alkaloids in their diets, because their adults transfer that substance to the egg masses (Orr et al., 1996; Pasteels, 2007), suggesting that alkaloids incorporated into diets can act as protective substances against pests (Eisner et al., 1986). Eleven alkaloids isolated from Swingle glutinosa (Rutaceae) showed antiparasitic activity in strains of Plasmodium falciparum (Haemosporida: Plasmodidae), Trypanosome brucei rhodesiense (Trypanosomatida: Trypanosomae) and Leishmania donovani (Trypanosomatida: Trypanosomae) (Santos et al., 2009).

Triterpenes and steroids were the second class of secondary metabolites among the most abundant compounds in the Asteracae species. Pentaciclic triterpenes have great potential in the development of agricultural. These compounds show insecticidal and antifeedant activities, especially those with skeletons of ursan, olenan, and lupan types (Pungitore et al., 2005; Omar et al., 2007; McLean et al., 2009). The isolation of triterpenes from Asteraceae extracts can provide structures with insecticidal activity. Moreover, the concentration of the bioactive triterpenes salanin and nimbin, along with seed size and oil content in Azadirachta indica (Meliaceae) trees from India varied from region to region and from tree to tree (Sidhu et al., 2004).

The methodology used for the quantification of polyphenols in plant samples of Asteraceae was appropriate, as shown by the high reproducibility of analytical results measured in the range $(\mathrm{y}=0.0087 \mathrm{x}+0.0273$, $\left.\mathrm{R}^{2}=0.9934\right)$ and low coefficient variation. The total phenolics of the extracts of these weeds ranged from $32.65 \pm 0.70$ (L. ramosissima) to $147.97 \pm 2.66 \mathrm{mg} \mathrm{g}^{-1}$ (L. ericoides). The amount of polyphenols varied among species Lychnophora with $32.65 \pm 0.70 \mathrm{mg} \mathrm{g}^{-1}$ for L. ramosissima, $54.03 \pm 0.73 \mathrm{mg} \mathrm{g}^{-1}$ for Lychnophora sp., and $147.97 \pm 2.66 \mathrm{mg} \mathrm{g}^{-1}$ for L. ericoides; and Lepidaploa with $141.11 \pm$ $1.99 \mathrm{mg} \mathrm{g}^{-1}$ for L. lilacina, and $73.22 \pm$ $1.18 \mathrm{mg} \mathrm{g}^{-1}$ for L. rufogrisea (Table 3). The wide variation in the concentration of polyphenols among species and genera suggests that these compounds cannot be used as chemotaxonomic markers.
Table 3 - Total phenol content (mean \pm standard deviation) and coefficient of variation (\%) of ethanol extracts of leaves of 12 species of Asteraceae expressed in milliequivalents of gallic acid per $100 \mathrm{~g}$ of extract

\begin{tabular}{|l|c|c|}
\hline \multicolumn{1}{|c|}{ Species } & $\begin{array}{c}\text { Mill. of gallic } \\
\text { acid/100g of extract }\end{array}$ & $\begin{array}{c}\text { Variation } \\
\text { coeficient }\end{array}$ \\
\hline Ageratum fastigiatum & $62.91 \pm 1.68$ & 3.34 \\
\hline Chromolaena chaseae & $88.20 \pm 0.57$ & 1.03 \\
\hline Eremanthus elaeagnus & $134.61 \pm 7.81$ & 15.09 \\
\hline Lepidaploa lilacina & $141.11 \pm 1.99$ & 3.56 \\
\hline Lepidaploa rufogrisea & $73.22 \pm 1.18$ & 2.30 \\
\hline Lychnophora sp. & $54.03 \pm 0.73$ & 1.27 \\
\hline Lychnophora ericoides & $147.97 \pm 2.66$ & 4.82 \\
\hline Lychnophora ramosissima & $32.65 \pm 0.70$ & 1.38 \\
\hline Mikania nummularia & $63.18 \pm 0.41$ & 0.81 \\
\hline Trichogonia villosa & $63.38 \pm 0.33$ & 0.58 \\
\hline Trixis glutinosa & $95.27 \pm 1.50$ & 2.94 \\
\hline Echinocoryne holosenicea & $68.94 \pm 0.94$ & 1.84 \\
\hline
\end{tabular}

The high variation in concentration of polyphenols in extracts of Asteraceae weeds indicates that their quantification by the reaction of the complex-tungsten-phosphorusmolybdate may not have shown the relation between the presence, emergence and spread of S. frugiperda (Tavares et al., 2009). Molecular structures or mixtures of them in each extract may be responsible for the biological activities of these extracts (Ayres et al., 1997; Ossipov et al., 2001; Heil et al., 2002). The selectivity of extracts of T. villosa and T. glutinosa, which contain flavonoids, to $T$. pretiosum and $T$. remus shows that products of these species are promising for programs of Integrated Pest Management (Tavares et al., 2009). Anthocyanins may protect seeds from predation (Briscoe \& Chittka, 2001) and leaves from attack by aphids (Ramírez et al., 2008). Flavonoids decreased the infestation of herbivores after damage to the leaves (Mäntylä et al., 2004), which shows the importance of these compounds as pest repellent. Astilbin, a flavonoid glycoside isolated to large amounts of flowers and stems of Dimorphandra mollis (Fabaceae), has broad insecticidal activity and has caused the mortality of agricultural pests and social insects (Pereira et al., 2002; Cintra et al., 2002, 2005a, b). 
Phenolic content in extracts of Asteraceae weeds appear to have insecticidal activity, mainly in relation to the species Lepidoptera, Orthoptera, and Hymenoptera, all with alkaline digestive systems. The species of these families were sensitive to the ingestion of these compounds in artificial diets (Berenbaum, 1980; Pereira et al., 2002; Cintra et al., 2002) as were Orygia leucostigma (Lepidoptera: Lymantriidae), and Helicoverpa zea (Lepidoptera: Noctuidae) with higher deformity of pupae and mortality of larvae when feeding on phenol due to oxidation of tissues in the midgut (Barbehenn et al., 2001). Moreover, caterpillars of Heliothis virescens (Lepidoptera: Noctuidae) fed with leaves rich in phenols had healthier hemolymph, suggesting increased free radical activity in the digestive system of insects when fed with these compounds (Johnson \& Felton, 2001), while the Manduca sexta (Lepidoptera: Sphingidae) presented contradictory results (Johnson, 2005). Spodoptera frugiperda fed with phago-inhibitors showed weight loss, increased duration of larval and pupal stages and less vigorous offspring (Tanzubil \& McCaferry, 1990). Moreover, phenolic compounds produce Reactive Oxygen Species (ROS) in the digestive process, which can affect the cells of the digestive tract and precipitate proteins and digestive enzymes, which decreases the absorption of nutrients and affects the diameter and length of head capsule stages of S. frugiperda and Anticarsia gemmatalis (Lepidoptera: Noctuidae) (Pereira et al., 2002).

Phytochemicals from the extracts of the Asteraceae weeds of campos rupestres of Diamantina in Minas Gerais State, Brazil may provide substances with potential for pest control and drugs.

\section{ACKNOWLEDGEMENTS}

To "Conselho Nacional de Desenvolvimento Científico e Tecnológico (CNPq)", "Coordenação de Aperfeiçoamento de Pessoal de Nivel Superior (CAPES)", and "Fundação de Amparo a Pesquisa do Estado de Minas Gerais (FAPEMIG)" for financial support. To "Group Solucion" of Brazil for translating this manuscript to English.

\section{LITERATURE CITED}

AYRES M. P. et al. Diversity of structure and antiherbivore activity in condensed tannins. Ecology, v .78, n. 6, p. 1696-1712, 1997.

BARBEHENN, R. V. et al. Antioxidant defenses in caterpillars: role of the ascorbate-recycling system in the midgut lumen. J. Insect Physiol., v. 47, n. 4-5, p. 349-357, 2001.

BERENBAUM, M. Adaptive significance of midgut $\mathrm{pH}$ in larval Lepidoptera. Am. Natural., v. 115, n. 1, p. 138-146, 1980.

BERNAYS, E. A.; DRIVER, G. C.; BILGENER, M. Herbivores and plant tannins. Adv. Ecol. Res., v. 19, n. 1, p. 263-302, 1989.

BRISCOE, A. D.; CHITTKA, L. The evolution of color vision in insects. Annu. Rev. Entomol., v. 46, n. 1, p. 471-510, 2001.

CINTRA, P. et al. Astilbin toxicity to leaf-cutting ants Atta sexdens rubropilosa (Hymenoptera: Formicidae).

Sociobiology, v. 45, n. 2, p. 347-353, 2005a.

CINTRA, P. et al. Toxicity of Dimorphandra mollis to workers of Apis mellifera. J. Braz. Chem. Soc., v. 13, n. 1, p. 115-118, 2002.

CINTRA, P. et al. Oral toxicity of chemical substances found in Dimorphandra mollis (Caesalpiniaceae) against honeybees (Apis mellifera) (Hymenoptera: Apidae). Sociobiology, v. 45, n. 1, p. 141-149, 2005b.

EISNER, T. et al. Defensive alkaloid in blood of Mexican bean beetle Epilachna varivestis. Experientia, v. 42, n. 2, p. 204-207, 1986.

FUNK, V. A. et al. Classification of Compositae. In: FUNK, V. A. et al. (Eds.) Systematics, evolution, and biogeography of the compositae. Vienna, Austria: International Association for Plant Taxonomy (IAPT), 2009. p. 171-189.

HEIL, M. et al. Extraction and quantification of "condensed tannins" as a measure of plant anti-herbivore defence? Revisiting an old problem. Naturwissenschaften, v. 89, n. 11, p. 519-524, 2002.

HIND, D. J. N. A checklist of the Brazilian Senecioneae (Compositae). Kew Bull., v. 48, n. 2, p. 279-295, 1993.

ISMAN, M. B. The role of botanical insecticides, deterrents, and repellents in modern agriculture and an increasingly regulated world. Ann. Rev. Entomol., v. 51, n. 1, p. 45-66, 2006. 
JOHNSON, K. S. Plant phenolics behave as radical scavengers in the context of insect (Manduca sexta) hemolymph and midgut fluid. J. Agric. Food Chem., v. 53, n. 26, p. 10120-10126, 2005.

JOHNSON, K. S.; FELTON, G. W. Plant phenolics as dietary antioxidants for herbivorous insects: a test with genetically modified tobacco. J. Chem. Ecol., v. 27, n. 12, p. 2579-2597, 2001.

LÓPEZ, R.; POTTER, D. A. Ant predation on eggs and larvae of the black cutworm (Lepidoptera: Noctuidae) and Japanese beetle (Coleoptera: Scarabaeidae) in turfgrass.

Environ. Entomol., v. 29, n. 1, p. 116-125, 2000.

MACÊDO, M. E. et al. Screening of Asteraceae (Compositae) plant extracts for larvicidal activity against Aedes fluviatilis (Diptera: Culicidae). Mem. Inst. Oswaldo Cruz, v. 92, n. 4, p. 565-570, 1997.

MÄNTYLÄ, E.; KLEMOLA, T.; HAUKIOJA, E. Attraction of willow warblers to sawfly-damaged mountain birches: novel function of inducible plant defences? Ecol. Letters, v. 7, n. 10, p. 915-918, 2004.

MCLEAN, S. et al. Papyriferic acid, an antifeedant triterpene from birch trees, inhibits succinate dehydrogenase from liver mitochondria. J. Chem. Ecol., v. 35, n. 10, p. 1252-1261, 2009.

MUELLER-HARVEY, I. Analysis of hydrolysable tannins. Anim. Feed Sci. Technol., v. 91, n. 1-2, p. 3-20, 2001.

NAKAJIMA, J. et al. Asteraceae. In: Lista de Espécies da Flora do Brasil. Rio de Janeiro: Jardim Botânico do Rio de Janeiro, 2010. Disponível em: <http://floradobrasil.jbrj.gov.br/ 2010/FB000055>. Acesso em: 20 mar. 2012.

OKUNADE, A. L. Ageratum conyzoides L. (Asteraceae). Fitoterapia, v. 73, n. 1, p. 1-16, 2002.

OMAR, S. et al. Antifeedant activities of terpenoids isolated from tropical Rutales. J. Stored Prod. Res., v. 43, n. 1, p. 92-96, 2007.

ORR, A. G. et al. Sequestration of pyrrolizidine alkaloids by larvae of Tellervo zoilus (Lepidoptera: Ithomiinae) and their role in the chemical protection of adults against the spider Nephila maculata (Araneidae). Chemoecology, v. 7, n. 2, p. 68-73, 1996.

OSSIPOV, V. et al. Phenolic and phenolic-related factors as determinants of suitability of mountain birch leaves to an herbivorous insect. Biochem. System. Ecol., v. 29, n. 3, p. 223-240, 2001.
PASTEELS, J. M. Chemical defence, offence and alliance in ants-aphids-ladybirds relationships. Popul. Ecol., v. 49, n. 1, p. 5-14, 2007.

PEREIRA, L. G. B. et al. Biological activity of astilbin from Dimorphandra mollis against Anticarsia gemmatalis and Spodoptera frugiperda. Pest Manag. Sci., v. 58, n. 5, p. 503-507, 2002.

PETACCI, F. et al. Inhibition of peroxidase activity and scavenging of reactive oxygen species by astilbin isolated from Dimorphandra mollis (Fabaceae, Caesalpinioideae). Biol. Res., v. 43, n. 1, p. 63-74, 2010.

POTTER, D. A. et al. Contribution of ergot alkaloids to suppression of a grass-feeding caterpillar assessed with gene knockout endophytes in perennial ryegrass. Entomol. Exp. Appl., v. 126, n. 2, p. 138-147, 2008.

PUNGITORE, C. R. et al. Insecticidal and antifeedant effects of Junellia aspera (Verbenaceae) triterpenes and derivatives on Sitophilus oryzae (Coleoptera: Curculionidae). J. Stored Prod. Res., v. 41, n. 4, p. 433-443, 2005.

RAMÍREZ, C. C.; LAVANDERO, B.; ARCHETTI, M. Coevolution and the adaptive value of autumn tree colours: colour preference and growth rates of a southern beech aphid. J. Evol. Biol., v. 21, n. 1, p. 49-56, 2008.

SANTOS, D. A. P. et al. Antiparasitic activities of acridone alkaloids from Swinglea glutinosa (Bl.) Merr. J. Braz. Chem. Soc., v. 20, n. 4, p. 644-651, 2009.

SCHOFIELD, P.; MBUGUA, D. M.; PELL, A. N. Analysis of condensed tannins: a review. Anim. Feed Sci. Technol., v. 91, n. 1-2, p. 21-40, 2001.

SIDHU, O. P.; KUMAR, V.; BEHL, H. M. Variability in triterpenoids (nimbin and salanin) composition of neem among different provenances of India. Ind. Crop Prod., v. 19, n. 1, p. 69-75, 2004.

TANZUBIL, P. B.; MCCAFERRY, A. R. Effects of azadirachtin and aqueous neem seed extracts on survival, growth and development of the African armyworm, Spodoptera exempta. Crop Protec., v. 9, n. 5, p. 383-386, 1990.

TAVARES, W. S. et al. Potential use of Asteraceae extracts to control Spodoptera frugiperda (Lepidoptera: Noctuidae) and selectivity to their parasitoids Trichogramma pretiosum (Hymenoptera: Trichogrammatidae) and Telenomus remus (Hymenoptera: Scelionidae). Ind. Crop Prod., v. 30, n. 3, p. 384-388, 2009. 
TAVARES, W. S. et al. Deleterious activity of natural products on postures of Spodoptera frugiperda (Lepidoptera: Noctuidae) and Diatraea saccharalis (Lepidoptera: Pyralidae). Z. Naturforsch. C, v. 65, n. 5-6, p. 412-418, 2010a.

TAVARES, W. S. et al. Selective effects of natural and synthetic insecticides on mortality of Spodoptera frugiperda (Lepidoptera: Noctuidae) and its predator Eriopis connexa (Coleoptera: Coccinellidae). J. Environ. Sci. Heal. B, v. 45, n. 6, p. 557-561, 2010b.

TAVARES, W. S. et al. Insecticide activity of piperine: Toxicity to eggs of Spodoptera frugiperda (Lepidoptera: Noctuidae) and Diatraea saccharalis (Lepidoptera: Pyralidae) and phytotoxicity on several vegetables. J. Med. Plants Res, v. 5, n. 21, p. 5301-5306, 2011.

TELES, A. M.; NAKAJIMA, J. N.; STEHMANN, J. R. Senecio albus, a new species of Senecio sect. Adamantina (Senecioneae - Asteraceae) with an emendment to the section. Kew Bull., v. 64, n. 1, p. 161-165, 2009.
VAN LOON, J. J. A.; DE VOS, E. W.; DICKE, M. Orientation behaviour of the predatory hemipteran Perillus bioculatus to plant and prey odours. Entomol. Exp. Appl., v. 96 , n. 1 , p. 51-58, 2000.

VIANNA, U. R. et al. Insecticide toxicity to Trichogramma pretiosum (Hymenoptera: Trichogrammatidae) females and effect on descendant generation. Ecotoxicology, v. 18, n. 2, p. 180-186, 2009.

ZANUNCIO, J. C. et al. Insecticide selectivity to Supputius cincticeps (Stal) (Het. Pentatomidae) and its prey Spodoptera frugiperda (J. E. Smith) (Lep. Noctuidae). J. Appl. Entomol., v. 122, n. 8, p. 457-460, 1998.

ZANUNCIO, T. V. et al. Permethrin-induced hormesis on the predator Supputius cincticeps (Stål, 1860) (Heteroptera: Pentatomidae). Crop Protec., v. 22, n. 7, p. 941-947, 2003.

ZANUNCIO, T. V. et al. Fertility and life expectancy of the predator Supputius cincticeps (Heteroptera: Pentatomidae) exposed to sublethal doses of permethrin. Biol. Res., v. 38, n. 1, p. 31-39, 2005. 